The Amish Population: County Estimates and Settlement Patterns - Donnermeyer, Anderson and Cooksey

\title{
The Amish Population: County Estimates and Settlement Patterns ${ }^{1}$
}

Joseph F. Donnermeyer ${ }^{2}$

Professor of Rural Sociology

Environmental Social Science Program

School of Environment and Natural Resources

The Ohio State University

Cory Anderson

OSU Presidential Fellow and Doctoral Candidate in Rural Sociology

School of Environment and Natural Resources

The Ohio State University

Elizabeth C. Cooksey

Professor, Department of Sociology, and

Associate Director, Center for Human Resource Research

The Ohio State University

\begin{abstract}
This article presents the findings of a county-based estimate of the Amish population. The results are from work commissioned by the Association of Statisticians of American Religious Bodies for the recently released 2010 U.S. Religion Census, plus research and updates associated with tracking the growth and geographic spread of Amish settlements in North America. County estimates are restricted to Amish church groups who rely on horse-and-buggy for travel. Using the terminology of the larger ASARB report, we break the Amish population into three groups: communicants (baptized members), non-baptized members (mostly children/young adults still living at home), and adherents (both baptized and non-baptized Amish). We report on population totals, state by state. We include tables showing the 25 largest Amish settlements, the 25 counties with the largest Amish populations, and the 25 counties with the highest percentage of Amish to their total population. Based on current rates of growth, we project the Amish population, decade by decade, to 2050 .
\end{abstract}

Keywords: Amish, census, settlement, church districts

\section{Erratum (updated November 2013)}

Pg. 83, Table 1. Estimate for baptized members per church district and young adults / nonbaptized children per church district for settlements three to five years old is reversed. It is now 35 for baptized members and 68 for non-baptized members. 
Journal of Amish and Plain Anabaptist Studies, Volume 1, Issue 1 (April), 2013

\section{Introduction}

American society may be without equal in the diversity of its religious groups. A combination of constitutional rights which restrain government sponsorship of a specific faith and two-plus centuries of immigration of people who carry with them the theological beliefs and social organization of denominations and sects from their countries of origin, are the base for this religious menagerie. Today, many churches promote and market their creeds through electronic media, from radio to the web, in much the same way as any other franchised business found in the ubiquitous shopping malls that mark so much of contemporary American life. And, like savvy shoppers, many Americans stroll about the malls of faith searching for the store they like the best. New fellowships emerge as church leaders and lay people alike bicker and disagree over the proper interpretation of a holy book, adding even more religious diversity to the fabric of American society, like so many patches on a quilt.

No other church group is more closely associated with the quilt today than the Amish. Ironically, the Amish were slow to adopt quilt making, only taking it up sometime in the latter half of the 1800s, nearly 150 years after they began to emigrate to North America from German-speaking areas along the Rhine River. Today, however, it is one of most enduring and endearing symbols Americans stereotypically associate with the Amish (Granick 1989; Walbert 2002).

Most Americans who watch only faux-reality and hugely inaccurate programs about the Amish on cable TV (e.g., "Amish: Out of Order" - on the National Geographic Channel - one of the worst), or read only occasional news stories about Amish who get into trouble with the law or to whom a tragedy occurred, merely see a single, undifferentiated group of rural-located people. They notice that the Amish are distinctive in several visible ways, but may not understand why. They can see that the Amish maintain a strict division of labor between husbands as breadwinners and wives as homemakers, have large families, dress differently, speak a dialect of German known as "Pennsylvania Dutch," rely on horse and buggy for local travel, and generally follow an austere lifestyle devoid of many comforts afforded by urban living and electricity. Millions of tourists, mostly from the city, flock to so-called "Amish country" areas each year, but rarely learn much about them, spending most of their time at kitschy antique and gift shops, and restaurants who claim to serve up Pennsylvania Dutch or Amish cooking (Buck 1978).

In fact, the Amish are a highly diverse group of people who maintain a degree of separation (based on their interpretation of the Christian bible) from whatever mainstream society surrounds them. This has been their history since the Anabaptist (i.e., 
The Amish Population: County Estimates and Settlement Patterns - Donnermeyer, Anderson and Cooksey

to be rebaptized) movement began during the early days of the Protestant Reformation in the $16^{\text {th }}$ century. The Amish are a branch of the Anabaptist movement, and it is generally accepted that the year 1693 is when they first formed. They are named for one of their ministers who was a leader of the succession movement from another Anabaptist group, the Swiss Brethren. His name was Jacob Ammann (Hostetler 1993; Nolt 2003).

After decades of persecution in Europe, Anabaptists, including the Amish, and many other religious minorities across Europe took advantage of opportunities to settle in the frontier areas of Pennsylvania and other British colonies. As the U.S. and later, Canada, gained their independence from Great Britain, waves of mostly Europeans immigrants moved west during the 1800s, displacing, decimating, and dominating various Native American societies. The Amish were never far behind these European pioneers, seeking places to settle where they could practice their religious philosophy of separation from the world without a great deal of disturbance from others, and where land for farming and other economic endeavors was available (Nolt 2003). Then, in the $20^{\text {th }}$ century, when the structure of American society transformed to a predominately urban, industrial mode, the Amish eschewed most of the new technologies in the interest of sustaining tight-knit church groups and a simpler lifestyle, set in rural locations.

This paper reviews the results from research commissioned by the Association of Statisticians of American Religious Bodies (ASARB), who recently published the 2010 U.S. Religion Census (Grammich et al. 2012). Also known as the "Religious Congregations and Membership Study" (RCMS), it is an attempt to provide county-based estimates of "religious bodies" in the U.S. Our population estimates are for the year 2010, however, we include updated information through December 31, 2012 on the number of settlements (that is, new ones founded in 2011 and 2012).

Our work, as summarized in this paper, includes county (or county equivalent) estimates for 2010 of the Amish population living for the U.S., supplemented by a count of Amish from settlements in the Canadian province of Ontario. We begin by describing the social organization of the Amish because this forms the basis for understanding the methods we used to conduct a county-based census of their population.

The Amish are growing faster than almost any other subculture, religious or nonreligious, in North America. One reason is that they are a "high fertility" group (Hewner 1998; Greska 2002; Cooksey and Donnermeyer 2004; 2012). For the Amish, large families are an expression both of religious convictions and of a people whose economy is based on agriculture and other manual trades where the labor of children is valued. 
Further, the Amish prefer occupations that do not require men to commute long distances and to be absent from the home for considerable periods of time, and it is expected that married women will be homemakers and not work outside the home (Kreps, Donnermeyer, and Kreps 1994). This creates a strong form of socialization in which the daughters and sons born into Amish families increasingly decide as young adults to be baptized into the faith and begin families of their own (Greska and Korbin 2002), especially when considered against the backdrop of how much of a lifestyle adjustment would need to be made should they decide to join a non-Amish church (Stevick 2007). For this reason, as America transformed through the $20^{\text {th }}$ century to the kind of society it is today, a growing share of their children elected to remain Amish. The combination of large families and high rates of baptism has created a population boom that is unprecedented in the history of the Amish. In preparation for this paper, we calculated a current doubling time for the Amish population of 21.25 years, ${ }^{3}$ which in turn has inspired a geographic spread of Amish communities into many new rural localities across North America (Donnermeyer and Cooksey 2010).

\section{Social Organization of the Amish}

To understand how we conducted our county-based census of the Amish, we first o describe two important features of Amish society (in addition to the family unit), namely, the church and the settlement.

\section{The Amish Church}

The Amish are a sect (Hostetler 1993; McQuire 2003). However, unlike other sects in American society that emphasize individualistic in expressions of faith, the Amish opt for a communal and conformist style. A fundamental building block of Amish society is the church, which for the Amish is intentionally kept small scale in its organization. Referred to as "church districts" by the Amish, a single district typically consists of a few dozen families whose baptized members have nominated and then selected by a type of lottery (in conformance with passages found in the Acts of the Apostles of the New Testament) four men to be their ordained church leaders, including a bishop, two ministers, and a deacon. Whenever the size of a district grows larger than 40 or so families, it will divide into two districts, each with its own set of church leaders. This intentional pursuit of small-scale social organization is a symbol of their separation or difference from most other religious groups found in North America (Kraybill 1989; Hostetler 1993). In fact, the Amish refer to their church districts as gemeinde, or use the short-forms of gemee and gmay, words which have the same root and essential meaning as Tönnies original formulation of gemeinschaft (DeFlem 1999). 
The Amish Population: County Estimates and Settlement Patterns - Donnermeyer, Anderson and Cooksey

The congregation or "communicants" of a single Amish church district consists of all baptized members, both men and women. The Amish believe that only adult baptism is legitimate, which was one of the fundamental reasons why Anabaptists (i.e., to be rebaptized) broke off from the Catholics, Lutherans and other Protestant groups in Europe during the first half of the $16^{\text {th }}$ century. Infant baptism was one way governments kept both tax rolls and preserved lists of possible male conscripts for the military (Beachy 2010).

The baptized members of a church district, under the guidance of the ordained leaders, determine the church discipline, which in the Pennsylvania Dutch dialect of the Amish is known as the ordnung. The Amish review and revise the ordnung of their church district twice each year, before the Sunday service at which the sacrament of communion is administered. In general, any decision about changes in the ordnung of a church district is congregational in style, based on consent of all or nearly all baptized members (Kreps, Donnermeyer, and Kreps 1997).

Unlike many large membership denominations, such as that found in the Roman Catholic Church, there is no hierarchy of church leaders beyond those selected by the baptized members of each church district; although there are periodic meetings of bishops who discuss and debate issues related to religious values and lifestyle choices, and how these should be expressed through the ordnung. Along with a congregational style of decision-making, the Amish can be described as maintaining a "flattened" form of social organization and as a "strong tie" church (Iannaccone 1992). Each church district may have a slightly different ordnung from every other church district, which is a primary source of diversity within the Amish, but this pattern also serves to maintain a high degree of involvement and conformity among the members of each church district. To be baptized Amish means taking a vow to obey the Ordnung, thus symbolizing their obedience to the will of God. It may seem ironic, but at the same time as the Amish seek to be non-conformist with reference to the secular mainstream of American society, they also stipulate a high degree of conformity among themselves. Members who deviate from the ordnung may be asked to publicly confess during a church service, and eventually, a persistent and serious offender may be excommunicated and shunned (Hostetler 1993; Kraybill and Bowman 2001).

The Amish are unique in that they do not meet for their biweekly Sunday service in a church building. Church buildings are for the fancy or "high" churches, not the low or "old order." Instead, services are held at the home of a member, and generally rotate from residence to residence throughout the year. Since travel to the service is by horse and buggy, this compels Amish families from the same church district to live close by each 


\section{Journal of Amish and Plain Anabaptist Studies, Volume 1, Issue 1 (April), 2013}

other. Hence, their small-scale, communal orientation to religion and lifestyle requires a certain amount of geographic proximity.

\section{The Amish Settlement}

The Amish refer to the places where they live and worship as "settlements." A settlement is the second essential building block in the social structure of the Amish. It is like a community insofar as it is a delimited geographic space in which the Amish share common goals, interests, and communal activities (Kraybill 1989; Liepins 2000). However, it is not a community in the sense of a place with a legally defined jurisdiction or boundary. In almost all Amish settlements, there are many more "English,” (a nickname the Amish give to their non-Amish neighbors) than there are Amish. As Hostetler (1993, p 91) notes, settlements are not “...discrete villages, counties, or compounds...,” but rather are places where a cluster or group of Amish families are "living in a contiguous relationship." In fact, there are only a few, rare places, where the Amish are concentrated to the extent that they represent a substantial proportion of the local population.

\section{One Final Note}

We restrict this paper to a reporting of the Amish population. Due to various disagreements over religious beliefs and lifestyle practices throughout the history of the Anabaptists in North America, there have been numerous schisms and fissions among the Amish (Nolt 2003). This has led to a wide variety of groups who identify themselves as “Amish” (Waldrep 2008; Anderson 2011). Many of these are quite progressive in their use of technologies, such as car ownership. In this census, we restrict our count solely to church groups who call themselves Amish and who have maintained a horse-and-buggy lifestyle, as well as avoiding, restricting or re-inventing the use of other forms of technology that would otherwise "yoke" them to the world. ${ }^{4}$ There are Amish fellowships ranging from the hyper-conservative "Swartzentrubers" who prohibit such conveniences as indoor plumbing, to the "New Order Amish" who are much more open to the use of electronic technologies, especially in their businesses, but still maintain a horse and buggy lifestyle (Hurst and McConnell 2010). The largest fellowship, representing about 80 percent of all Amish included in our county-based census, is known as the "Old Order Amish." We refer to the full range, from Swartzentruber to New Order, as the Amish, a collective phrase to distinguish them from more progressive Amish-Mennonite groups (Anderson 2011). 
The Amish Population: County Estimates and Settlement Patterns - Donnermeyer, Anderson and Cooksey

\section{The Amish Census: Methods}

The Religious Congregational Membership Survey, sponsored in part by the Association of Statisticians of American Religious Bodies, is an attempt to provide county-based information on religious membership in the U.S. Its most recent report was released on May 1, 2012 under the title 2010 U.S. Religious Census. For the large membership denominations, like Catholic, Baptist, Lutheran, and Methodist, a central registry of members may be available. For many smaller sects, including the Amish, RCMS commissions specialists who are familiar with the religious group to collect the information.

The 2010 U.S. Religion Census (Grammich et al. 2012) includes counts for most religious groups of both "communicants" or fully participating members, and "adherents," which is all members of the church, including those who do not fully participate or are not considered members until they are baptized or in some other way gain formal admission. Since the Amish practice adult baptism, our count included "baptized members" as communicants, plus children and young adults not yet baptized who still live with their Amish parents. Adding both groups together creates the total for "adherents," and therefore, a count or census of the Amish population.

As building blocks for Amish social structure, both the church district and settlement determined, in large part, the method by which a county-by-county census of the Amish was conducted. Without a church hierarchy, there is no central registry of Amish church membership. Amish settlements themselves range in size from a few families in single-district to a few large settlements with thousands of families, hundreds of church districts, and a variety of cultural practices as expressed through the various districts' ordnungs.

We were asked to develop county-based estimates of the Amish population, including both baptized members and non-baptized members in the U.S. However, to be inclusive, we extended our count to the 15 settlements located in Ontario.

\section{Settlement Criteria}

We first decided to rely on a definition of an Amish settlement developed by David Luthy. Luthy is one of the owners of the Heritage Historical Library in Aylmer, Ontario and has kept track and published a directory of Amish settlements and their approximate locations for the past several decades. His definition is as follows: 


\section{Journal of Amish and Plain Anabaptist Studies, Volume 1, Issue 1 (April), 2013}

To be included in this directory, a new settlement must initially have at least three resident households - or two, if one household head is in the ministry...Formerly active settlements are not included if church services are no longer held, even though a few families or members may still reside there (Luthy 2009, p 1).

Further, Luthy's definition stipulates that the Ordnung must not be so permissive as to allow car ownership. This minimalist definition of an Amish settlement displays all the elements contained in both classic (Hillery 1955; Warren 1963) and contemporary (Liepins 2000) sociological delineations of community, specifying a delimited geographic area in which forms of collective action based on common interests among actors who occupy this common space emerge. Further, this minimalist approach has the advantage of incorporating nearly all Amish, even though there may be a handful of uncounted, isolated families in places where a church service cannot be held, and therefore, a core display of community through religious fellowship, is not able to occur. Needless to say, if a small settlement with a single church district makes a decision to own automobiles, it is no longer counted in this census. Finally, a minimalist approach allows little room for a subjective interpretation of what constitutes a settlement. Hence, we adopted Luthy's (2009) definition and his list of settlements as the basis on which the number and location of the Amish population, county-by-county, was made.

\section{Settlement Directories}

Our next step was to gather as many recent directories of Amish families, church districts, and settlements as we could find. Most of these directories are compiled and published by members of various Amish communities, or by individuals who belong to conservative Anabaptist groups with access to these communities. Regardless of the church membership of authors, all rely on various paper documents distributed to Amish families, and which ask them to provide their address, birth and marriage dates for adults household members, birth dates of all children and other pieces of information that vary across directories, such as occupation of the male householder and baptism status of the children. These directories are sold and distributed among the Amish and other Anabaptist groups, and serves to keep track of where other Amish settlements and families across North America are located. The Heritage Historical Library attempts to collect and maintain on its shelves as many of these directories as can be found. We utilized information from 62 of these directories as a primary database from which this census was conducted.

Directory information is usually organized by church district. Within each church district, a listing of each household and all household members is then provided. In 
The Amish Population: County Estimates and Settlement Patterns - Donnermeyer, Anderson and Cooksey

addition to the household address and important family dates, many directories include a "code" or letter next to the name of a daughter or son which indicates their baptism status. All offspring are listed, including adult children who have married, and in most directories, the name of their spouse and where they live is also included. Offspring who are married and living in the same settlement are not only listed under their parents' name, but are also included as a separate household. We made sure not to double-count offspring who were baptized Amish and subsequently married and formed their own family.

Both the baptism code and offspring information allowed us to more exactly count the number of persons living in the same household, and whether or not they were baptized members. Further, most directories include a map of each church district, showing the roads where everyone lives. If a church district straddles a county border, this is also shown, or can be determined through inspections of a hard copy atlas or a web-based source like Google Earth.

Some of the directories report statistics for several dozen settlements from the same or adjoining states, while others are specific to a single (and usually, larger) settlement. Archival information at the Heritage Historical Library also identified members of various Amish settlements who had developed directories for their communities, who we contacted for the most recent editions, and if available, purchased a copy of our own. Nevertheless, numerous trips to the Heritage Historical Library greatly helped in completion of this project.

\section{Sources for Settlement News}

Unfortunately, directories are not available for every Amish church district and settlement, and not every directory was published recently. For example, there are directories that include most of the Amish settlements in Kentucky in both 1998 and 2004, but none more recent. To supplement the base of information available from which the current estimates were derived, other sources were consulted. Three important sources are monthly magazines which publish periodic news about the Amish. These news sources are The Budget (Sugarcreek, Ohio), The Diary (Bart, Pennsylvania), and Die Botschaft (Millersburg, Pennsylvania). The Budget is actually the local Sugarcreek newspaper which as early as the 1880s began to include reports from scribes in Amish communities located across Canada and the U.S. Today, all three news sources include periodic reports from "scribes" about births, deaths, marriages, migrations, visitors to the community, the weather, and accidents. Scribes are volunteers who usually take on the responsibility as a way of contributing to the community. These reports function like the 


\section{Journal of Amish and Plain Anabaptist Studies, Volume 1, Issue 1 (April), 2013}

"town crier" of bygone days, and serve to keep the hundreds of autonomous Amish communities connected to each other.

Each year, in a winter issue (usually in January or February) of these news sources, the scribe will report the "settlement statistics" from the previous year. Many reports include the number of households currently residing in the settlement, and the number of church districts as well. These household numbers form a primary source of information for estimating population settlement size when directory information was lacking.

In addition to the three newspapers, an annual publication called Raber's Almanac is published which includes a list of most but not all church districts and the bishop, minister(s), and deacon associated with each. The information is organized by state, county, and settlement, and can be used to estimate Amish populations when little other information is available. It is also useful for estimating county distributions of the population for settlements which straddle county lines because addresses of the church leaders are included. Hence, if no other information was available, The New American Almanac (Raber 2012) allowed for estimates for settlements rated 7 and 8 on a confidence scale as described in Table 2 below.

\section{Counting Up Baptized (Communicants) and Non-Baptized Members}

Population size for each settlement was developed, either by counting up the number of baptized and non-baptized persons, church district by church district when recent directories provided sufficient information, or by means of extrapolation for settlements when directory information was not as recent or for which no directory information was available. If information for a settlement was available from a directory published within the five years prior to 2010, and from one published earlier (but no more than five years earlier than the more recent directory), the formula of adjusted average annual population change was applied to create a 2010 estimate. This population growth formula is: $\mathrm{P}(\mathrm{t})=\mathrm{P}(\mathrm{o})^{*} \exp (\mathrm{rt})$, where $\mathrm{P}(\mathrm{t})$ is the population at end-point, $\mathrm{P}(\mathrm{o})$ is the population at starting-point, Exp is the exponential operator for the value of $\mathrm{rt}, \mathrm{r}$ is growth rate (per unit of time), and $\mathrm{t}$ is the number of time-unit.

A second way we estimated the population for this census was to calculate the average number of baptized and non-baptized members in a single household using information from published directories and apply this to an average number of households per church district. Information on average household size from 129 settlements was used to establish the averages found in Table1. We also adjusted our figures based on the age of a settlement, which greatly assisted in developing estimates for newly founded communities where little demographic information currently exists. 
The Amish Population: County Estimates and Settlement Patterns - Donnermeyer, Anderson and Cooksey

The demographics of the Amish, especially household size, has varied very little over the past several decades (Cooksey and Donnermeyer 2004) enabling us to incorporate information from older directories and hence increase the size of the database from which average household sizes and church district sizes were derived. For baptized members per church district, non-baptized children/young adults per church district, and total estimated population, whole numbers were used.

Averages for communities ten years old or younger were developed from directory information for settlements where there was only one church district. One hundred-thirty such settlements formed the statistical base for these averages. Information from the most recent directory for three of the four largest Amish communities (Greater Holmes County, Ohio; Elkhart/Lagrange/Noble Counties, Indiana; and Geauga/Trumbull Counties, Ohio) was used to develop the averages for communities 11 years and older which contain more than one church district.

For the most part, the conservative group known as the Swartzentruber Amish do not allow themselves to be listed in directories because they believe it brings too much attention to the individual; however, another conservative group, the Andy Weaver (Dan) Amish, mostly do not have such reservations. Averages from four Andy Weaver communities (and a total of 19 church districts), all located in Ohio, were used as a proxy to estimate the Swartzentruber population, when necessary.

Table 1 displays the averages that were applied to settlements where no or insufficient directory information was available. If one of the three Amish news sources reported the number of households in the settlement, then the simple process of multiplication provided the population estimate. A less accurate but last resort for estimating the size of a settlement was to determine the age of the settlement and apply the average number of households, baptized members, and non-baptized members.

As can be seen in Table 1, the average number of baptized members per household varied little by the age of a single district sized settlement, however, the average number of non-baptized members did vary by settlement age. In general, older settlements have fewer non-baptized members per household, and part of this reason may be that older teenagers are frequently sent to live with relatives at other localities, where they apprentice in a business and where it is hoped they meet their future marriage partner. Also, most (but not all) less progressive Amish have higher fertility, hence, a larger number of non-baptized members per household (Wasao and Donnermeyer 1992). 


\section{Table 1: Estimated Household and Church District Size, by Age of Settlement}

\begin{tabular}{|c|c|c|c|c|c|c|}
\hline $\begin{array}{l}\text { (1) Age of } \\
\text { settlement } \\
\text { (number of } \\
\text { settlements } \\
\text { used to } \\
\text { determine } \\
\text { averages) }\end{array}$ & $\begin{array}{c}\text { Baptized } \\
\text { members } \\
\text { per } \\
\text { household }\end{array}$ & $\begin{array}{c}\text { Non- } \\
\text { baptized } \\
\text { children } \\
\text { / young } \\
\text { adults } \\
\text { per } \\
\text { household }\end{array}$ & $\begin{array}{c}\text { Households } \\
\text { per } \\
\text { church } \\
\text { district }\end{array}$ & $\begin{array}{l}\text { Baptized } \\
\text { members } \\
\text { per } \\
\text { church } \\
\text { district }\end{array}$ & $\begin{array}{c}\text { Non- } \\
\text { baptized } \\
\text { children } \\
\text { / young } \\
\text { adults } \\
\text { per } \\
\text { church } \\
\text { district }\end{array}$ & $\begin{array}{c}\text { Total } \\
\text { estimated } \\
\text { population }\end{array}$ \\
\hline $\begin{array}{c}\text { Single } \\
\text { district } \\
\text { settlements }\end{array}$ & & & & & & \\
\hline $\begin{array}{c}\text { Less than } 1 \\
\text { year }\end{array}$ & 2.13 & 3.64 & 3* & 6 & 11 & 17 \\
\hline $\begin{array}{c}1-2 \text { years } \\
(n=22)\end{array}$ & 2.13 & 3.64 & 11.2 & 24 & 41 & 65 \\
\hline $\begin{array}{c}\text { 3-5 years } \\
(\mathrm{n}=31)\end{array}$ & 2.43 & 4.71 & 14.5 & 35 & 68 & 103 \\
\hline $\begin{array}{c}\text { 6-10 years } \\
(n=32)\end{array}$ & 2.32 & 4.22 & 18.5 & 43 & 78 & 121 \\
\hline $\begin{array}{l}11 \text { years } \\
\text { and older } \\
(n=44)\end{array}$ & 2.04 & 3.19 & 22.9 & 47 & 73 & 120 \\
\hline $\begin{array}{c}11 \text { years } \\
\text { and older - } \\
2 \text { or more } \\
\text { church } \\
\text { districts** }\end{array}$ & 2.21 & 2.64 & 29.0 & 63 & 81 & 143 \\
\hline $\begin{array}{c}\text { Less } \\
\text { progressive } \\
\text { Amish } \\
\text { settlements, } \\
\text { any age**** }\end{array}$ & 2.34 & 3.98 & 24 & 56 & 96 & 152 \\
\hline
\end{tabular}

*The number of households reflects the minimalist definition of a settlement as 3 households (Luthy, 2009) and averages established for settlements 1-3 years old.

**Averages based on information from directories for: Elkhart-Lagrange-Noble Counties, Indiana; Nappanee, Indiana; Adams-Jay-Geneva, Indiana; Old Order church districts in the Greater Holmes County Directory; and Geauga/Trumbull Counties, Ohio.

***Averages based on averages from 19 church districts of less progressive (than Old Order Amish) groups included in the Greater Holmes County directory for Lakeville, Ohio, Gallipolis, Ohio and the Greater Holmes County settlement, plus the Fredericktown/Belleville, Ohio settlement. 
The Amish Population: County Estimates and Settlement Patterns - Donnermeyer, Anderson and Cooksey

Since, by definition an Amish community must have at least three households, the simple rule of assuming three households was used for settlements less than a year old if no other information was available. Both size of household and size of church district estimators for settlements one to two years old were assumed for these newborn settlements (Table 1).

Another problem to be solved was that not every directory provided information on the baptism status of daughters and sons who are living at home. Since older children begin to make decisions about baptism sometime in their late teens, it was impossible to distinguish between baptized members or communicants from non-baptized members, both of whom could still live at home with their parents. However, a couple cannot marry in the church without first being baptized. Hence, it was safe to presume that all husbands and wives listed in a directory were baptized members.

Using directories in which information about the baptism status of daughters and sons was available allowed us to calculate a correction factor that adjusted both the number for baptized adults and for the number of single, non-baptized members. We derived this correction factor from over 500 church districts found in directories that did contain information about the baptism status of children. This figure was 1.124532 and designates that for every ten baptized Amish men and women who are married and living in a church district, there are actually 11.24532 baptized members. In other words, some single daughters and sons still living at home are baptized members at the time the directory information was submitted, even though they may marry and perhaps migrate to a new settlement soon after. It is also possible that some extra baptized members are older relatives who live independently. Our correction factor also accounts for any elderly or indigent adults who live in the same household, plus adult children who never married and stayed at home, but nonetheless became members of the Amish church. For directories where no baptism status was indicated, we therefore applied this corrections factor to the number of married persons and then subtracted the revised estimate of baptized members from the total number of people in the church district. Hence, it adjusted the numbers for baptized and non-baptized members without changing the population count (i.e., number of adherents).

\section{Confidence of Estimates}

We developed an 8-point scale was developed to rate the confidence of the population estimates for each Amish community or settlement (Table 2), where a rating of 1 indicates the most confident estimate. Below is a brief description of each confidence level. The reader should note that for the least confident ratings (\#7 and \#8), 


\section{Journal of Amish and Plain Anabaptist Studies, Volume 1, Issue 1 (April), 2013}

two additional sources were consulted, namely, the publication of Amish settlements by David Luthy (2009), and The New American Almanac. The latter is an annual publication listing church leaders for almost every Amish church district. As well, Luthy's (2009) list of Amish settlements includes the number of church districts for each. Hence, if no other information was available, then we used population estimates based solely on the number of church districts in a settlement, based on one or both of these two sources. Below is a brief description of each confidence rating.

Rating 1: count of members and nonmembers for a settlement from directory information at two points in time, with one count less than five years old (i.e., published since 2005). The population growth formula was used to extrapolate to 2010, if necessary

Rating 2: count of baptized and non-baptized members for a settlement from directory information at two points in time, with neither count less than five years old (i.e., published before 2005). Directory information was used to calculate the average number of baptized and non-baptized members per household specifically for that settlement. The most recent information on the number of households from one or more of the three Amish news sources, multiplied by the average number of baptized and non-baptized members per household for that settlement, was used to estimate the population.

Rating 3: count of baptized and non-baptized members from directory information for a settlement at one point in time, with the count less than five years old (i.e., published since 2005). Directory information was used to calculate the average number of baptized and non-baptized members per household specifically for that settlement. The most recent information on the number of households from one or more of the three Amish news sources, multiplied by the average number of baptized and non-baptized members per household for that settlement, was used to estimate the population.

Rating 4: count of baptized and non-baptized members from directory information for a settlement at one point in time, with the count less than five years old (i.e., published since 2005), but no recent supplemental information from any of the three Amish news sources. Population estimates were based on pre-calculated averages of baptized and non-baptized members per household, adjusted by settlement size (number of church districts) and the age of the settlement (see Table 1).

Rating 5: count of baptized and non-baptized members from directory information for a settlement at one point in time, with the count more than five years old (i.e., 
The Amish Population: County Estimates and Settlement Patterns - Donnermeyer, Anderson and Cooksey

published before 2005). Directory information was used to calculate the average number of baptized and non-baptized members per household specifically for that settlement. The most recent information on the number of households from one or more of the three Amish news sources, multiplied by the average number of baptized and non-baptized members per household for that settlement, was used to estimate the population.

Rating 6: no counts from directory information for a settlement were available, but recent information from one or more of the three Amish news sources was available for estimation of baptized and non-baptized members using precalculated averages of household size, adjusted by settlement size (number of church districts) and age of the settlement (see Table 1)

Rating 7: count of members and nonmembers from directory information for a settlement at one or more points in time, with all counts more than five years old, and with no recent information from one or more of the three Amish news sources. Population estimate for the settlement based on pre-calculated averages for settlement size (number of church districts) and age of the settlement, and information on the number of church districts determined from Luthy's Amish Settlements Across America, 2009 and/or The New American Almanac (Raber 2012).

Rating 8: no count from directory information and no information from any of the three Amish news sources. Population estimate for the settlement based on precalculated averages for settlement size (number of church districts) and age of the settlement, and information on the number of church districts determined from Luthy's Amish Settlements Across America, 2009 and/or The New American Almanac (Raber 2012)

Table 2 summarizes the confidence level for estimates for the 461 settlements and 1,873 church districts found for this census of the Amish. Almost 35 percent of settlements were assigned a rating of " 1 ," but because they tend to be the larger and older settlements, they represented over half of all church districts. Using church district as a proxy for population size, what this means is that slightly over half of the Amish population was estimated from recently published directories, and those counts were deemed to have the highest accuracy. Any source of error was likely small and more likely due to how the information was collected for publication in the directory, something over which we have no control. 
Journal of Amish and Plain Anabaptist Studies, Volume 1, Issue 1 (April), 2013

Nearly half of the settlements were assigned a rating of "6" or lower, but represented less than a quarter of all church districts. In particular, the 91 settlements assigned a rating of 7 or 8 , but representing less than 10 percent of all church districts, are the shakiest estimates because only pre-calculated averages of baptized and non-baptized members per household, adjusted for the age of the settlements, could be used. At least for the 134 settlements assigned a rating of 6 , the number of households was

Table 2: Amish Population Estimates: Confidence Ratings

\begin{tabular}{|l|c|c|c|c|}
\hline Confidence Level & $\begin{array}{c}\text { Number of } \\
\text { Settlements }\end{array}$ & Percent & $\begin{array}{c}\text { Number of } \\
\text { Church } \\
\text { Districts }\end{array}$ & Percent \\
\hline 1 (most confident) & 160 & 34.71 & 999 & 53.33 \\
\hline 2 & 10 & 2.17 & 57 & 3.04 \\
\hline 3 & 21 & 4.56 & 74 & 3.95 \\
\hline 4 & 12 & 2.60 & 22 & 1.17 \\
\hline 5 & 33 & 7.16 & 318 & 16.98 \\
\hline 6 & 134 & 29.07 & 239 & 12.76 \\
\hline 7 & 15 & 3.25 & 52 & 2.78 \\
\hline 8 (least confident) & 76 & 16.49 & 112 & 5.98 \\
\hline Total & 461 & 100.00 & 1,873 & 100.00 \\
\hline
\end{tabular}

known. However, if in any of those settlements, the actual average number of baptized or non-baptized members varied greatly from the pre-calculated averages, there will be error in our estimates. For example, a relatively small settlement may contain several families with an unusually large number of children, hence, we would under-estimate the number of non-baptized members there. Additionally, we have no way to attest for the accuracy of a scribe's report, but given the small-scale nature of the social organization of both church districts and settlements, we are reasonably confident that a scribe's count of households was correct or nearly so.

Overall, despite sources of error, our multiple method approach to estimating the number of baptized and non-baptized members of Amish is an improvement over previous attempts, which used only the average size of a church district multiplied by the number of church districts in a settlement (Young Center 2011). This simpler method tends to overestimate the population because it fails to account for variation in settlement size by age, and does not break down the estimate between baptized and non-baptized 
The Amish Population: County Estimates and Settlement Patterns - Donnermeyer, Anderson and Cooksey

members. Further, it cannot account for the Amish population on a county-by-county basis.

\section{The Amish Census: Findings}

\section{Population Estimates for States}

Table 3 displays the Amish population, by state, for number of settlements, baptized members ("communicants"), non-baptized members, total persons ("adherents"), and number of church districts. Again, as a reminder to readers, the population figures are for 2010, while settlement numbers in Table 4 have been updated through 2012 and include two new states - Idaho and Wyoming.

The results indicate that church districts in Pennsylvania and Indiana are slightly larger, on average, than in Ohio, which also has the largest number of church districts among all of the states. In part, this is due to the greater number of new settlements in Ohio when compared to the other two states (see Table 4).

In total, there were nearly 251,000 Amish (i.e., “adherents”), of whom 105,482 were "communicants" or baptized members and 145,289 were non-baptized members in 2010. The three leading states by population size in 2010 were Ohio, Pennsylvania, and Indiana. Ohio was ahead of Pennsylvania by slightly more than a 1,000 persons or adherents. Indiana's Amish population estimate was one shy of 45,000 persons.

The states of Michigan, New York and Wisconsin now contain populations of baptized and non-baptized members exceeding 10,000. If population growth continues at its current pace, both Missouri and Kentucky's Amish populations will soon exceed 10,000 as well. Further, we should note that our 2010 "snapshot" of the population will need to be revised regularly to keep pace with population increase and settlement growth.

The 1,873 Amish church districts were spread across 28 states at the time of the 2010 census, and the Canadian province of Ontario. Between 2010 and 2012, Amish settlements were established in both Idaho and Wyoming (see Table 4). The preponderance of settlements and most of the Amish are located in more northerly states, stretching from New York through the Midwestern region to Minnesota (and the southern region of Ontario). However, there is growth in states in the Southern region which border on the Midwest, especially Kentucky and Missouri, plus a growing presence in Tennessee. Settlements in Colorado and Montana, along with the most recent settlements in Idaho and Wyoming, may foreshadow a greater presence in the Western region for the 
Journal of Amish and Plain Anabaptist Studies, Volume 1, Issue 1 (April), 2013

Table 3: Amish Population by State/Province (2010)

\begin{tabular}{|c|c|c|c|c|}
\hline $\begin{array}{c}\text { State / } \\
\text { Province }\end{array}$ & $\begin{array}{c}\text { Number of } \\
\text { Baptized } \\
\text { Members } \\
\text { (communicants) }\end{array}$ & $\begin{array}{c}\text { Number } \\
\text { of } \\
\text { Non- } \\
\text { Members }\end{array}$ & $\begin{array}{c}\text { Total } \\
\text { Number } \\
\text { of Persons } \\
\text { (adherents) }\end{array}$ & $\begin{array}{c}\begin{array}{c}\text { Number } \\
\text { of } \\
\text { Church } \\
\text { Districts }\end{array} \\
\end{array}$ \\
\hline Arkansas & 43 & 79 & 122 & 2 \\
\hline Colorado & 122 & 213 & 335 & 5 \\
\hline Delaware & 610 & 814 & 1,424 & 10 \\
\hline Florida & 111 & 14 & 125 & 1 \\
\hline Illinois & 2,730 & 3,648 & 6,378 & 47 \\
\hline Indiana & 19,361 & 25,638 & 44,999 & 304 \\
\hline Iowa & 2,800 & 4,488 & 7,288 & 55 \\
\hline Kansas & 586 & 739 & 1,325 & 12 \\
\hline Kentucky & 3,285 & 5,169 & 8,454 & 71 \\
\hline Maine & 100 & 186 & 286 & 5 \\
\hline Maryland & 588 & 643 & 1,231 & 11 \\
\hline Michigan & 4,058 & 6,352 & 10,410 & 88 \\
\hline Minnesota & 1,138 & $1, \mathbf{8 8 8}$ & 3,026 & 28 \\
\hline Mississippi & 65 & 110 & 175 & 1 \\
\hline Missouri & 3,738 & 6,155 & 9,893 & 82 \\
\hline Montana & 169 & 210 & 379 & 4 \\
\hline Nebraska & 95 & 180 & 275 & 3 \\
\hline New York & 4,898 & 7,307 & 12,205 & 104 \\
\hline $\begin{array}{c}\text { North } \\
\text { Carolina }\end{array}$ & 70 & 77 & 147 & 1 \\
\hline Ohio & 26,895 & 33,413 & 60,308 & 445 \\
\hline Oklahoma & 301 & 290 & 591 & 6 \\
\hline Ontario & 1,832 & 2,562 & 4,394 & 35 \\
\hline Pennsylvania & 26,233 & 33,792 & 59,025 & 404 \\
\hline South Dakota & 19 & 33 & 52 & 1 \\
\hline Tennessee & 775 & 1,313 & 2,088 & 15 \\
\hline Texas & 18 & 29 & 47 & 1 \\
\hline Virginia & 240 & 401 & 641 & 6 \\
\hline West Virginia & 79 & 137 & 216 & 3 \\
\hline Wisconsin & 5,532 & 9,409 & 14,932 & 121 \\
\hline Total & 105,501 & 145,347 & 250,848 & 1,873 \\
\hline
\end{tabular}


The Amish Population: County Estimates and Settlement Patterns - Donnermeyer, Anderson and Cooksey

for the Amish. Plus, there is now an Amish settlement in the Upper Peninsula of Michigan, five in Maine, and three in the northern areas of Ontario where farming as a way of life would be difficult, if not impossible, due to short growing seasons.

\section{Amish Settlements and Population Growth}

Table 4 and Figure 1 show the growth of settlements through the history of the Amish in North America, including updated statistics which account for the newest of all settlements founded in 2011 and 2012. Over 63 percent of the 463 settlements were founded since 1990. Ninety-four settlements which still exist today were started in the 1990s, 198 in the first decade of this new century, and another 58 in 2010-2012. ${ }^{5}$ On average, and accounting for new settlements during this period which are already extinct (not shown in Table 4), since 1990 there has been a new settlement founded about every 3.41 weeks, or 15.25 on average annually. Further, the rate increases with time. During the 1990s (and again, taking into consideration new settlements which are already extinct), a new settlement was founded, on average, every 5.33 weeks, compared to an average of 3.25 weeks for the first three years of this century's second decade.

An inspection of the table indicates that one reason Ohio now has the largest population of Amish is that it continues to play host to new settlements, with 34 of its 54 settlements founded since 1990. Most of these are in its southeastern, “Appalachian” region, the most rural region of the state. In contrast, a majority of settlements in both Indiana and Pennsylvania were founded prior to 1990.

Of the 35 new settlements founded in 2011 and 2012, 13 are west of the Mississippi River, including three each in Iowa and Minnesota. Some states have witnessed dramatic increases in the number of Amish settlements founded over the past 22 plus years, especially Kentucky, Missouri, and Wisconsin. However, in no state is the growth of settlements more dramatic than New York. Just since 2010, 15 new settlements have been established in the Empire State (plus 1 more, which is already extinct), which equals the total number of settlements there prior to 2000. New York now ranks third, behind Ohio and Pennsylvania, in the number of extant settlements (48), even though its Amish population (Table 3 ) is much smaller. 
Journal of Amish and Plain Anabaptist Studies, Volume 1, Issue 1 (April), 2013

Table 4: Extant Amish Settlements, by State and Founding Years

\begin{tabular}{|c|c|c|c|c|c|c|c|c|c|c|}
\hline State & $\begin{array}{c}1760 \text { - } \\
1899\end{array}$ & $\begin{array}{c}1900- \\
1949\end{array}$ & $\begin{array}{c}1950- \\
1969\end{array}$ & $\begin{array}{c}1970- \\
1989\end{array}$ & $\begin{array}{c}1990- \\
1999\end{array}$ & $\begin{array}{c}2000- \\
2009\end{array}$ & 2010 & 2011 & 2012 & Total \\
\hline Arkansas & & & & & & 2 & & & & 2 \\
\hline Colorado & & & & & & 3 & & 1 & 1 & 5 \\
\hline Delaware & & 1 & & & & & & & & 1 \\
\hline Florida & & 1 & & & & & & & & 1 \\
\hline Idaho & & & & & & & & & 1 & 1 \\
\hline Illinois & 1 & & & & 5 & 11 & 1 & & & 18 \\
\hline Indiana & 6 & & 3 & 4 & 5 & 4 & & 1 & & 23 \\
\hline Iowa & 1 & 1 & 1 & 3 & 4 & 7 & 2 & 3 & & 22 \\
\hline Kansas & 2 & 1 & & & & 4 & & & & 7 \\
\hline Kentucky & & & 1 & 8 & 7 & 11 & 3 & 4 & & 34 \\
\hline Maine & & & & & & 3 & & 1 & 1 & 5 \\
\hline Maryland & 1 & & 1 & & 1 & & & & & 3 \\
\hline Michigan & & 1 & 2 & 15 & 9 & 8 & 1 & & 2 & 38 \\
\hline Minnesota & & & & 4 & 2 & 7 & & 1 & 2 & 16 \\
\hline Mississippi & & & & & 1 & & & & & 1 \\
\hline Missouri & & 1 & 4 & 6 & 6 & 18 & 2 & 1 & 1 & 39 \\
\hline Montana & & & & 1 & 2 & 1 & & & & 4 \\
\hline Nebraska & & & & & & 2 & 1 & & & 3 \\
\hline New York & & 1 & & 10 & 4 & 18 & 6* & 6 & 3 & 48 \\
\hline $\begin{array}{c}\text { North } \\
\text { Carolina }\end{array}$ & & & & & 1 & & & & & 1 \\
\hline Ohio & 3 & 1 & 6 & 10 & 16 & 14 & 4 & & & 54 \\
\hline Oklahoma & & 1 & & 1 & & & 1 & & 1 & 4 \\
\hline Ontario & 1 & & 5 & 2 & 3 & 4 & & & & 15 \\
\hline Pennsylvania & 4 & 4 & 11 & 20 & 7 & 7 & & 1 & & 54 \\
\hline $\begin{array}{c}\text { South } \\
\text { Dakota } \\
\end{array}$ & & & & & & & 1 & & & 1 \\
\hline Tennessee & & 1 & 1 & & 1 & 3 & & & & 6 \\
\hline Texas & & & & & 1 & & & & & 1 \\
\hline Virginia & & & & & 2 & 2 & & & 1 & 5 \\
\hline $\begin{array}{c}\text { West } \\
\text { Virginia }\end{array}$ & & & & & 1 & 2 & & & & 3 \\
\hline Wisconsin & & 1 & 3 & 13 & 16 & 11 & 1 & 1 & 1 & 47 \\
\hline Wyoming & & & & & & & & 1 & & 1 \\
\hline Total & 19 & 15 & 38 & 97 & 94 & 142 & 23 & 21 & 14 & 463 \\
\hline Percent & 4.10 & 3.24 & 8.21 & 20.95 & 20.30 & 30.67 & 4.97 & 4.54 & 3.02 & \\
\hline $\begin{array}{c}\text { Cumulative } \\
\text { Percent }\end{array}$ & 4.10 & 7.34 & 15.55 & 36.50 & 56.80 & 87.47 & 92.44 & 96.98 & 100.00 & \\
\hline
\end{tabular}

** One settlement in New York (Tyrone), founded in 2010, is already extinct. Technically, 7 settlements were founded in the "Empire State" that year. 
The Amish Population: County Estimates and Settlement Patterns - Donnermeyer, Anderson and Cooksey

\section{Figure 1: Extant Amish Settlements: 2012}

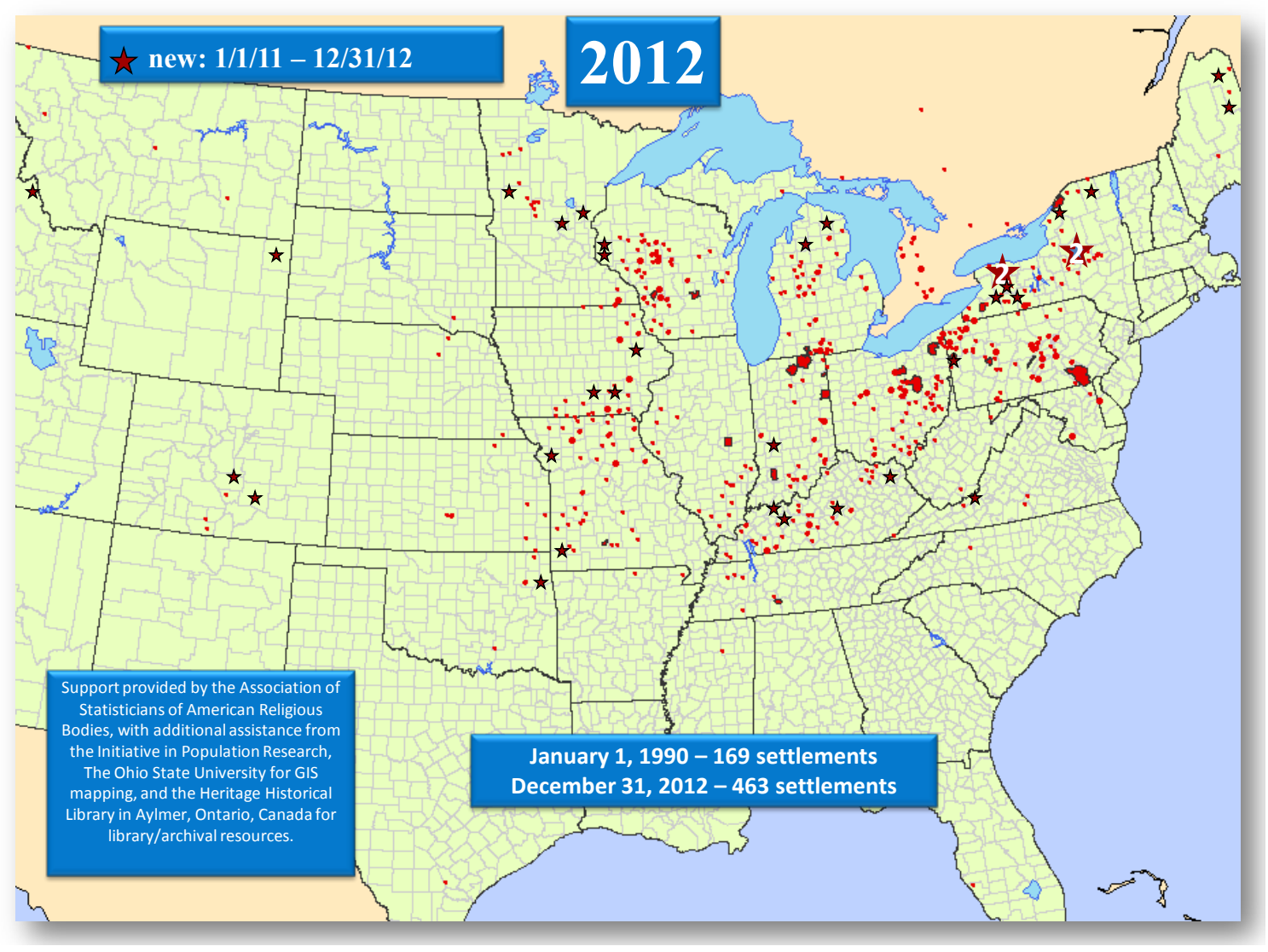

\section{Settlement Size}

Despite the explosive growth of new and smaller settlements, a majority of Amish still live in the larger settlements. This can be seen in Table 5, which shows the number of church districts by size of the settlement, based on the 2010 census calculations. There were 223 (51.98\%) settlements that were only one church district in size, but these communities represented only 11.92 percent of all districts. In contrast, there are four settlements with 50 plus church districts, but representing 33.62 percent of the districts. In fact, about 54 percent of the 1,873 church districts can be found in the 26 settlements in which are included 10 or more church groups. It is in many of these larger settlements that the diversity among Amish can be seen through variations in the church ordnung. For example, the largest Amish settlement is located in the Holmes County area of northeast Ohio, where even the casual observer can notice differences in buggy styles that 
reflect either the more progressive or less progressive ordnungs of various fellowships, from the New Order Amish to the Swartzentruber Amish (Hurst \& McConnell 2010).

Table 5: Size of Amish Settlements -

by Number of Church Districts (2010)

\begin{tabular}{|c|c|c|c|c|c|c|}
\hline $\begin{array}{c}\text { Number } \\
\text { of } \\
\text { Church } \\
\text { Districts }\end{array}$ & $\begin{array}{c}\text { Number of } \\
\text { Settlements }\end{array}$ & $\begin{array}{c}\text { Percentage } \\
\text { of } \\
\text { Settlements }\end{array}$ & $\begin{array}{c}\text { Cumulative } \\
\text { Percentage }\end{array}$ & $\begin{array}{c}\text { Number } \\
\text { of } \\
\text { Church } \\
\text { Districts }\end{array}$ & $\begin{array}{c}\text { Percentage } \\
\text { of Church } \\
\text { Districts }\end{array}$ & $\begin{array}{c}\text { Cumulative } \\
\text { Percentage }\end{array}$ \\
\hline 1 & 223 & 51.98 & 51.98 & 223 & 11.91 & 11.91 \\
\hline 2 & 86 & 20.05 & 72.03 & 172 & 9.18 & 21.09 \\
\hline 3 & 37 & 8.62 & 80.65 & 111 & 5.93 & 27.02 \\
\hline 4 & 21 & 4.90 & 85.55 & 84 & 4.48 & 31.50 \\
\hline $5-9$ & 36 & 8.40 & 93.95 & 277 & 14.79 & 46.29 \\
\hline $10-19$ & 17 & 3.96 & 97.91 & 217 & 11.59 & 57.88 \\
\hline $20-49$ & 5 & 1.17 & 99.08 & 160 & 8.54 & 66.42 \\
\hline$\geq 50$ & 4 & $\mathbf{0 . 9 3}$ & 100.01 & 629 & 33.58 & 100.00 \\
\hline Total & 429 & $100.01 *$ & & 1,873 & 100.00 & \\
\hline
\end{tabular}

\section{Population Centers}

Largest Amish Settlements: Tables 6, 7, and 8 display centers of the Amish population in three different ways, including: the 25 largest settlements by population size; the 25 counties or county equivalents with the largest Amish populations; and the 25 "most Amish" counties by the percent of the population which is Amish. As mentioned above, there are four Amish settlements containing that are larger than 50 church districts. A more detailed breakdown of their population, plus 21 other large settlements, is shown in Table 6. ${ }^{6}$ Just as the total populations of Amish in Ohio and Pennsylvania are nearly the same, so too is the total number of adherents in the two largest settlements the Greater Holmes County, Ohio community and the Lancaster/Chester Counties, Pennsylvania community. The population of the former is nearly 30,000, while the latter is almost 29,000. Family sizes are larger in the Lancaster/Chester counties settlements, which can be seen by the number of non-baptized members in both, whereas the number of baptized members (and also the number of church districts) is larger in the Greater Holmes County settlement.

Both the Elkhart/Lagrange/Noble Counties, Indiana and the Geauga/Trumbull Counties, Ohio settlements also exceed 10,000 in population. The latter is about half the size of the Greater Holmes County, Ohio settlement. Indiana also plays host to the next three largest settlements, namely, Berne/Monore/Geneva, Nappanee, and 
The Amish Population: County Estimates and Settlement Patterns - Donnermeyer, Anderson and Cooksey

Montgomery/Oden. Altogether, the 25 largest Amish settlements by population (i.e., “adherents”) represent 58 percent of all Amish and 53 percent of all church districts.

Pennsylvania and Indiana play host to five of the 25 largest settlements each, followed by Ohio, with four. The second largest settlement in the top 25 is also the oldest of all Amish settlements, namely, the Lancaster/Chester Counties, Pennsylvania community. In fact, the 11 largest settlements were all founded before 1900 . These settlements form the core or "mother" settlements from which almost all of the others can trace their origins, either directly because the first families to a new place came from there, or indirectly from other settlements who can trace their roots directly back to these original localities. The youngest settlement to make the list is the southern Kentucky community of Mumfordville/Horse Cave, Kentucky, which was founded only about 25 years ago.

Of special note is the proximity of some large settlements to each other. In particular, the settlements of Elkhart/Lagrange/Noble Counties (Indiana), Nappanee (Indiana) and Centreville (Michigan) are within a single day buggy ride of each other. If there is such a thing as an Amish "megalopolis," it is there.

Most Populous Counties, Amish Population: Many settlements, both large and small, cross county lines, and some even straddle state lines. As well, some counties are home to more than one settlement. This is shown in Table 7, which displays the 25 counties with the largest Amish populations. By a substantial margin, Lancaster County, Pennsylvania is the largest, at 26,270 total persons. The largest settlement, the Greater Holmes County, Ohio community, sprawls across six counties of northeastern Ohio, three of which are in the top 25 most populous counties. This includes Holmes County, at \# 2, with a population of 17,654 Amish, most of whom are from this largest of all settlements, but it is also the home for four other settlements, all of which are small and located on the border with another county. The Amish population of both Wayne County (\#5) and Tuscarawas County (\#18), even though both play host to a second settlement, are also largely composed of adherents included in the Greater Holmes County community.

Counties in Indiana and Ohio where large settlements are located represent the next seven counties with substantial Amish populations. Of special note is the tenth largest county, Crawford, located in western Pennsylvania. It is the home of nine settlements (either completely or partially), which is more than any other county in the U.S. or Canada, including one settlement it shares with the Ohio county of Ashtabula. ${ }^{7}$ As well, its neighbor to the south is Mercer County, Pennsylvania, in which another seven 
Journal of Amish and Plain Anabaptist Studies, Volume 1, Issue 1 (April), 2013

\section{Table 6: Twenty-five Largest Amish Settlements (2010)}

\begin{tabular}{|c|c|c|c|c|c|c|}
\hline $\begin{array}{c}\text { Name of } \\
\text { Settlement }\end{array}$ & Location & $\begin{array}{c}\text { Year } \\
\text { Founded }\end{array}$ & $\begin{array}{c}\begin{array}{c}\text { Number } \\
\text { of } \\
\text { Baptized }\end{array} \\
\text { Members }\end{array}$ & $\begin{array}{l}\text { Number } \\
\text { of Non- } \\
\text { members }\end{array}$ & $\begin{array}{c}\text { Total } \\
\text { Number } \\
\text { of } \\
\text { Persons }\end{array}$ & $\begin{array}{c}\begin{array}{c}\text { Number } \\
\text { of } \\
\text { Church }\end{array} \\
\text { Districts }\end{array}$ \\
\hline $\begin{array}{l}\text { 1. Greater } \\
\text { Holmes } \\
\text { County }\end{array}$ & $\begin{array}{c}\text { Northeast } \\
\text { Ohio }\end{array}$ & 1808 & 14,423 & 15,439 & 29,862 & 229 \\
\hline $\begin{array}{l}\text { 2. Lancaster / } \\
\text { Chester } \\
\text { Counties }\end{array}$ & $\begin{array}{c}\text { Southeast } \\
\text { Pennsylvania }\end{array}$ & 1760 & 12,607 & 16,289 & 28,356 & 180 \\
\hline $\begin{array}{l}\text { 3. Elkhart / } \\
\text { Lagrange / } \\
\text { Noble } \\
\text { Counties }\end{array}$ & $\begin{array}{l}\text { Northern } \\
\text { Indiana }\end{array}$ & 1848 & 8,711 & 11,283 & 19,994 & 132 \\
\hline $\begin{array}{l}\text { 4. Geauga / } \\
\text { Trumbull } \\
\text { Counties }\end{array}$ & $\begin{array}{c}\text { Northeast } \\
\text { Ohio }\end{array}$ & 1886 & 5,976 & 8,243 & 14,219 & 88 \\
\hline $\begin{array}{l}\text { 5. Berne / } \\
\text { Monroe / } \\
\text { Geneva }\end{array}$ & $\begin{array}{c}\text { West-central } \\
\text { Indiana and } \\
\text { western } \\
\text { Ohio }\end{array}$ & 1850 & 2,826 & 4,676 & 7,502 & 47 \\
\hline 6. Nappanee & $\begin{array}{l}\text { North- } \\
\text { central } \\
\text { Indiana }\end{array}$ & 1841 & 2,309 & 2,776 & 5,085 & 37 \\
\hline $\begin{array}{l}\text { 7.Montgomery / } \\
\text { Oden }\end{array}$ & $\begin{array}{l}\text { Southwest } \\
\text { Indiana }\end{array}$ & 1868 & 1,996 & 2,126 & 4,122 & 27 \\
\hline $\begin{array}{l}\text { 8. Arthur / } \\
\text { Arcola }\end{array}$ & $\begin{array}{l}\text { East-central } \\
\text { Illinois }\end{array}$ & 1864 & 1,810 & 2,028 & 3,838 & 27 \\
\hline $\begin{array}{l}\text { 9. Grabill / New } \\
\text { Haven }\end{array}$ & $\begin{array}{l}\text { Northwest } \\
\text { Indiana }\end{array}$ & 1852 & 1,513 & 1,953 & 3,466 & 19 \\
\hline $\begin{array}{l}\text { 10. Belleville } \\
\text { /Reedsville }\end{array}$ & $\begin{array}{c}\text { Central } \\
\text { Pennsylvania }\end{array}$ & 1791 & 1,389 & 1,634 & 3,023 & 22 \\
\hline $\begin{array}{l}\text { 11. New } \\
\text { Wilmington }\end{array}$ & $\begin{array}{l}\text { West-central } \\
\text { Pennsylvania }\end{array}$ & 1847 & 1,265 & 1,542 & 2,807 & 18 \\
\hline 12. Smicksburg & $\begin{array}{c}\text { Northwest } \\
\text { Pennsylvania }\end{array}$ & 1962 & 1,025 & 1,621 & 2,646 & 19 \\
\hline $\begin{array}{l}\text { 13. Seymour / } \\
\text { Fordland }\end{array}$ & $\begin{array}{l}\text { Southern } \\
\text { Missouri }\end{array}$ & 1968 & 758 & 1,494 & 2,252 & 13 \\
\hline
\end{tabular}


The Amish Population: County Estimates and Settlement Patterns - Donnermeyer, Anderson and Cooksey

\section{Table 6: Twenty-five Largest Amish Settlements (2010) - continued}

\begin{tabular}{|c|c|c|c|c|c|c|}
\hline $\begin{array}{c}\text { Name of } \\
\text { Settlement }\end{array}$ & Location & $\begin{array}{c}\text { Year } \\
\text { Founded }\end{array}$ & $\begin{array}{c}\begin{array}{c}\text { Number } \\
\text { of } \\
\text { Baptized } \\
\text { Members }\end{array} \\
\end{array}$ & $\begin{array}{c}\text { Number } \\
\text { of Non- } \\
\text { members }\end{array}$ & $\begin{array}{c}\text { Total } \\
\text { Number } \\
\text { of } \\
\text { Persons }\end{array}$ & $\begin{array}{c}\text { Number } \\
\text { of } \\
\text { Church } \\
\text { Districts }\end{array}$ \\
\hline $\begin{array}{l}\text { 14. Lodi / } \\
\text { Homerville }\end{array}$ & $\begin{array}{l}\text { Northeast } \\
\text { Ohio }\end{array}$ & 1952 & 788 & 1,360 & 2,148 & 14 \\
\hline 15. Cashton & $\begin{array}{l}\text { Southeast } \\
\text { Wisconsin }\end{array}$ & 1966 & 692 & 1,233 & 1,925 & 12 \\
\hline $\begin{array}{l}\text { 17. Conewango } \\
\text { Valley }\end{array}$ & $\begin{array}{l}\text { Southwest } \\
\text { New York }\end{array}$ & 1949 & 846 & 998 & 1,844 & 15 \\
\hline 16. Heuvelton & $\begin{array}{l}\text { Northern } \\
\text { New York }\end{array}$ & 1975 & 619 & 1,052 & 1,671 & 11 \\
\hline $\begin{array}{l}\text { 18. Munford- } \\
\text { ville / Horse } \\
\text { Cave }\end{array}$ & $\begin{array}{l}\text { Southern } \\
\text { Kentucky }\end{array}$ & 1989 & 653 & 914 & 1,567 & 13 \\
\hline 19. Centreville & $\begin{array}{c}\text { South- } \\
\text { central } \\
\text { Michigan }\end{array}$ & 1910 & 693 & 835 & 1,528 & 11 \\
\hline 20. Ethridge & $\begin{array}{c}\text { South- } \\
\text { central } \\
\text { Tennessee }\end{array}$ & 1944 & 563 & 957 & 1,520 & 10 \\
\hline $\begin{array}{l}\text { 21.Spartans- } \\
\text { burg }\end{array}$ & $\begin{array}{c}\text { Northwest } \\
\text { Pennsylvania }\end{array}$ & 1966 & 589 & 908 & 1,497 & 10 \\
\hline $\begin{array}{l}\text { 22. Kingston / } \\
\text { Dalton }\end{array}$ & $\begin{array}{c}\text { Central } \\
\text { Wisconsin }\end{array}$ & 1977 & 540 & 926 & 1,466 & 12 \\
\hline $\begin{array}{l}\text { 23.Fredicktown } \\
\text { / Bellville }\end{array}$ & Central Ohio & 1972 & 536 & 915 & 1,451 & 11 \\
\hline $\begin{array}{l}\text { 24. Dover / } \\
\text { Hartly }\end{array}$ & $\begin{array}{l}\text { Next to the } \\
\text { Dover, } \\
\text { Delaware } \\
\text { metropolitan } \\
\text { area }\end{array}$ & 1915 & 610 & 814 & 1,424 & 10 \\
\hline \multirow[t]{3}{*}{ 25. Kalona } & $\begin{array}{c}\text { East-Central } \\
\text { Iowa } \\
\end{array}$ & 1846 & 634 & 787 & 1,421 & 9 \\
\hline & & Total & 63,831 & 82,803 & 146,634 & 996 \\
\hline & & $\begin{array}{l}\text { Percent } \\
\text { of Amish }\end{array}$ & 60.50 & 56.97 & 58.46 & 53.18 \\
\hline
\end{tabular}




\section{Table 7: Twenty-Five Counties with Largest Amish Populations (2010)}

\begin{tabular}{|c|c|c|}
\hline County, State & Year Founded/Settlement Name & $\begin{array}{c}\text { Amish } \\
\text { Population }\end{array}$ \\
\hline $\begin{array}{l}\text { 1. Lancaster, } \\
\text { Pennsylvania }\end{array}$ & 1760 - Lancaster/Chester Counties (partial) & 26,270 \\
\hline 2. Holmes, Ohio & $\begin{array}{l}1808 \text { - Greater Holmes County (partial) } \\
1962 \text { - Lakeville/Big Prairie } \\
1990 \text { - Brinkhaven/Danville (partial) } \\
1991 \text { - Loudonville/McKay (partial) } \\
1994 \text { - Glenmont/Brinkhaven (partial) } \\
\quad \text { Total }\end{array}$ & $\begin{array}{c}17,042 \\
405 \\
50 \\
10 \\
147 \\
17,654\end{array}$ \\
\hline 3. Lagrange, Indiana & $\begin{array}{l}1841 \text { - Elkhart/Lagrange/Noble Counties } \\
\text { (partial) }\end{array}$ & 14,005 \\
\hline 4. Geauga, Ohio & 1886 - Geauga/Trumbull Counties (partial) & $\mathbf{8 , 5 3 7}$ \\
\hline 5. Wayne, Ohio & $\begin{array}{l}1808 \text { - Greater Holmes County (partial) } \\
1952 \text { - Lodi/Homerville (partial) } \\
\end{array}$ & $\begin{array}{c}8,367 \\
646 \\
9,283 \\
\end{array}$ \\
\hline 6. Adams, Indiana & 1850 - Berne/Monroe/Geneva (partial) & 6,343 \\
\hline 7. Elkhart, Indiana & $\begin{array}{l}1841 \text { - Nappanee (partial) } \\
1841 \text { - Elkhart/Lagrange/Noble Counties } \\
\text { Total }\end{array}$ & $\begin{array}{l}1,273 \\
4,971 \\
6,244 \\
\end{array}$ \\
\hline 8. Trumbull, Ohio & $\begin{array}{l}1886 \text { - Geauga/Trumbull Counties (partial) } \\
1975 \text { - Kinsman (partial) } \\
\text { Total }\end{array}$ & $\begin{array}{c}3,836 \\
28 \\
3,864 \\
\end{array}$ \\
\hline 9. Daviess, Indiana & 1868 - Montgomery/Oden (partial) & 3,709 \\
\hline $\begin{array}{l}\text { 10. Crawford, } \\
\text { Pennsylvania }\end{array}$ & $\begin{array}{l}1924 \text { - Atlantic (partial) } \\
1966 \text { - Spartansburg (partial) } \\
1969 \text { - Conneautville } \\
1972 \text { - Guys Mills } \\
1972 \text { - Townville } \\
1983 \text { - Union City (partial) } \\
1985 \text { - Linesville } \\
1994 \text { - Pierpont (Ohio) (partial) } \\
2006 \text { - Saegertown }\end{array}$ & \begin{tabular}{c|}
763 \\
1,418 \\
222 \\
340 \\
32 \\
173 \\
304 \\
123 \\
135 \\
3,510
\end{tabular} \\
\hline 11. Allen, Indiana & 1852 - Grabill/New Haven & 3,466 \\
\hline $\begin{array}{l}\text { 12. Mifflin, } \\
\text { Pennsylvania }\end{array}$ & 1791 - Belleville/Reedsville (partial) & 2,899 \\
\hline 13. Vernon, Wisconsin & $\begin{array}{l}1966 \text { - Cashton (partial) } \\
1985 \text { - Hillsboro (partial) } \\
1988 \text { - LaValle (partial) } \\
1990 \text { - Readstown (partial) } \\
1992 \text { - Viroqua/Dach Ridge } \\
1994 \text { - Viroqua/Chaseburg }\end{array}$ & $\begin{array}{c}1,377 \\
772 \\
10 \\
121 \\
90 \\
371 \\
2,741 \\
\end{array}$ \\
\hline
\end{tabular}


The Amish Population: County Estimates and Settlement Patterns - Donnermeyer, Anderson and Cooksey

\section{Table 7: Twenty-Five Counties with Largest Amish Populations (2010), continued}

\begin{tabular}{|c|c|c|}
\hline County, State & Year Founded/Settlement Name & $\begin{array}{c}\text { Amish } \\
\text { Population }\end{array}$ \\
\hline $\begin{array}{l}\text { 14. Chester, } \\
\text { Pennsylvania }\end{array}$ & 1760 - Lancaster/Chester Counties & 2,580 \\
\hline $\begin{array}{l}\text { 15. Indiana, } \\
\text { Pennsylvania }\end{array}$ & $\begin{array}{l}1962 \text { - Smicksburg (partial) } \\
1997 \text { - Homer City (partial) }\end{array}$ & $\begin{array}{c}2,415 \\
162 \\
2,577\end{array}$ \\
\hline $\begin{array}{l}\text { 16. Mercer, } \\
\text { Pennsylvania }\end{array}$ & $\begin{array}{l}1847 \text { - New Wilmington (partial) } \\
1924 \text { - Atlantic (partial) } \\
1942 \text { - Mercer } \\
1975 \text { - Kinsman (Ohio) (partial) } \\
1990 \text {-- Fredonia } \\
2006 \text { - Greenville } \\
2012 \text { - Carlton }\end{array}$ & $\begin{array}{c}1,456 \\
139 \\
596 \\
44 \\
194 \\
79 \\
17 \\
2,514\end{array}$ \\
\hline 17. Ashtabula, Ohio & $\begin{array}{l}1886 \text { - Geauga/Trumbull Counties (partial) } \\
1991 \text { - Dorset/Cherry Valley } \\
1992 \text { - Andover } \\
1994 \text { - Pierpont (partial) } \\
1997 \text { - Williamsfield } \\
2010 \text { - Cherry Valley }\end{array}$ & $\begin{array}{c}1,459 \\
71 \\
168 \\
570 \\
139 \\
65 \\
2,472\end{array}$ \\
\hline 18. Tuscarawas, Ohio & $\begin{array}{l}1808 \text { - Greater Holmes County (partial) } \\
1969 \text { - Peoli/Port Washington (partial) } \\
\text { Total }\end{array}$ & $\begin{array}{c}2,136 \\
234 \\
2,370\end{array}$ \\
\hline 19. Douglas, Illinois & 1864 - Arthur/Arcola (partial) & 2,361 \\
\hline 20. Kosciusko, Indiana & 1841 - Nappanee (partial) & 2,277 \\
\hline 21. Knox, Ohio & $\begin{array}{l}1964 \text { - Danville/Butler (partial) } \\
1972 \text { - Fredericktown/Belleville (partial) } \\
1987 \text { - Utica/Gambier (partial) } \\
1990 \text { - Brinkhaven/Danville (partial) } \\
1990 \text { - Walhonding/Warsaw (partial) } \\
2000 \text { - Howard/"East Knox" }\end{array}$ & $\begin{array}{c}420 \\
427 \\
533 \\
515 \\
55 \\
307 \\
2,257\end{array}$ \\
\hline 22. Webster, Missouri & 1968 - Seymour/Fordland & 2,252 \\
\hline 23. Clark, Wisconsin & $\begin{array}{l}1970 \text { - Spencer (partial) } \\
1975 \text { - Greenwood/Willard } \\
1981 \text { - Granton } \\
1989 \text { - Loyal } \\
1991 \text { - Owen } \\
2005 \text { - Neillsville }\end{array}$ & \begin{tabular}{c|}
68 \\
338 \\
886 \\
505 \\
193 \\
103 \\
2,093
\end{tabular} \\
\hline $\begin{array}{l}\text { 24. St. Lawrence, New } \\
\text { York }\end{array}$ & $\begin{array}{l}1974 \text { - Norfolk } \\
1975 \text { - Heuvelton } \\
2004 \text { - Nicolville/Potsdam (partial) }\end{array}$ & $\begin{array}{c}74 \\
1,671 \\
92 \\
1,837\end{array}$ \\
\hline $\begin{array}{l}\text { 25. Centre, } \\
\text { Pennsylvania }\end{array}$ & $\begin{array}{l}1950 \text { - Aaronsburg } \\
1967 \text { - Rebersburg/Brush Valley } \\
1973 \text { - Howard/Mill Hall (partial) } \\
1979 \text { - Spring Mills/Penns Valley }\end{array}$ & $\begin{array}{c}321 \\
787 \\
362 \\
\mathbf{3 6 6} \\
\mathbf{1 , 8 3 6}\end{array}$ \\
\hline
\end{tabular}




\section{Journal of Amish and Plain Anabaptist Studies, Volume 1, Issue 1 (April), 2013}

settlements are located, including one it also shares with Ohio. Also of note is that Ashtabula County in eastern Ohio is the home for six communities and borders on both Crawford and Mercer Counties in Pennsylvania. Plus, in the central Ohio county of Knox is located six settlements, one of which spills over into Holmes County. Finally, Clark County in central Wisconsin contains six settlements and is the $23^{\text {rd }}$ most populous Amish county.

Most Amish Counties - Percent: Amish settlements are mostly located in rural counties, but not all of the time. For example, the oldest and second largest settlement, Lancaster/Chester Counties, Pennsylvania, is situated in a large county geographically, has some of the most productive soils in the United States, and was very rural when the Amish settled there in the first half of the $18^{\text {th }}$ century (Hostetler, 1993). However, over the years it has grown into a sizeable county which the U.S. Bureau of the Census now classifies as metropolitan. With a population today exceeding 500,000, even though it is the most populous Amish county, only 5.17 percent of its population is Amish. This gives it a rank of only $22^{\text {nd }}$ on the list of the "most Amish" counties in North America.

By far, the most Amish counties by percentage of the population are Holmes, Ohio and Lagrange, Indiana. Unlike Lancaster County in Pennsylvania, both of these counties are more rural in character and have much smaller populations. Hence, the proportion of the population which is Amish is much higher - exceeding 42 percent in Holmes County and nearly 38 percent in Lagrange. The 2010 Census shows total populations (Amish and "English") of about 42,500 and 33,200 persons, respectively, for Holmes and Lagrange counties. Given the current doubling time of the Amish, and assuming that either natural increase (birth minus deaths), net migration (in-migration minus out-migration) or both in Holmes County among Amish families continues to spur population growth higher than among their "English" neighbors, it is possible that this county will gain the distinction of being the first majority Amish county sometime during the next 15-20 years. Lagrange County may not be far behind.

After Holmes and Lagrange, the next most Amish county in North America is Adams County in Indiana, which is on the eastern border with Ohio and is one of several counties which plays host to the large (ranked $5^{\text {th }}$ ) Berne/Monroe/Geneva settlement. There are three other counties whose Amish populations exceed 10 percent, including Davis County, Iowa (two settlements); Douglas County; Illinois (Arthur/Arcola settlement); and Daviess County, Indiana (Montgomery/Oden settlement). 
The Amish Population: County Estimates and Settlement Patterns - Donnermeyer, Anderson and Cooksey

\begin{tabular}{|c|c|c|c|}
\hline County, State & Year Founded/Settlement Name & $\begin{array}{c}\text { Amish } \\
\text { Population } \\
\text { (adherents) }\end{array}$ & $\begin{array}{l}\text { Percent of } \\
\text { County } \\
\text { Population }\end{array}$ \\
\hline 1. Holmes, Ohio & $\begin{array}{l}1808 \text { - Greater Holmes County (partial) } \\
1962 \text { - Lakeville/Big Prairie } \\
1990 \text { - Brinkhaven/Danville (partial) } \\
1991 \text { - Loudonville/McKay (partial) } \\
1994 \text { - Glenmont/Brinkhaven (partial) }\end{array}$ & $\begin{array}{c}17,042 \\
405 \\
50 \\
10 \\
147 \\
17,654\end{array}$ & 42.18 \\
\hline 2. Lagrange, Indiana & $\begin{array}{l}1841 \text { - Elkhart/Lagrange/Noble Counties } \\
\text { (partial) }\end{array}$ & 14,005 & 37.64 \\
\hline 3. Adams, Indiana & 1850 - Berne/Monroe/Geneva (partial) & 6,343 & 18.52 \\
\hline 4. Davis, Iowa & $\begin{array}{l}1969-\text { Milton/Pulaski (partial) } \\
1971 \text { - Bloomfield/Drakesville }\end{array}$ & $\begin{array}{c}146 \\
1,201 \\
1,374\end{array}$ & 16.05 \\
\hline 5. Douglas, Illinois & 1864 - Arthur/Arcola (partial) & 2,361 & 12.32 \\
\hline 6. Daviess, Indiana & 1868 - Montgomery/Oden (partial) & 3,709 & 12.12 \\
\hline 7. Vernon, Wisconsin & $\begin{array}{l}1966 \text { - Cashton (partial) } \\
1985 \text { - Hillsboro (partial) } \\
1988 \text { - LaValle (partial) } \\
1990 \text { - Readstown (partial) } \\
1992 \text { - Viroqua/Dach Ridge } \\
1994 \text { - Viroqua/Chaseburg }\end{array}$ & $\begin{array}{c}1,377 \\
772 \\
10 \\
121 \\
90 \\
371 \\
2,741 \\
\end{array}$ & 9.35 \\
\hline 8. Hart, Kentucky & $\begin{array}{l}1989 \text { - Munfordville/Horse Cave } \\
1991 \text { - Hardyville/Three Springs (partial) } \\
\text { Total }\end{array}$ & $\begin{array}{c}1,558 \\
143 \\
1,701\end{array}$ & 9.25 \\
\hline 9. Moultrie, Illinois & 1864 - Arthur/Arcola (partial) & 1,260 & 8.75 \\
\hline 10. Geauga, Ohio & 1886 - Geauga/Trumbull (partial) & 8,537 & 8.62 \\
\hline 11. Wayne, Ohio & $\begin{array}{l}1808 \text { - Greater Holmes County (partial) } \\
1952 \text { - Lodi/Homerville (partial) }\end{array}$ & $\begin{array}{c}8,367 \\
646 \\
9,283 \\
\end{array}$ & 8.13 \\
\hline 12. Daviess, Missouri & 1953 - Jamesport (partial) & 596 & 7.38 \\
\hline 13. Ringgold, Iowa & $\begin{array}{l}1994 \text { - Redding } \\
1997 \text { - Lamoni/Davis City (partial) } \\
2002 \text { - Diagonal }\end{array}$ & $\begin{array}{c}274 \\
27 \\
73 \\
374\end{array}$ & 7.56 \\
\hline 14. Van Buren, Iowa & $\begin{array}{l}1969 \text { - Milton/Pulaski (partial) } \\
2005 \text { - Bonaparte }\end{array}$ & $\begin{array}{l}390 \\
174 \\
564\end{array}$ & 7.34 \\
\hline
\end{tabular}




\section{Table 8: Twenty-Five Most Amish Counties - Percent of County Population (2010) continued}

\begin{tabular}{|c|c|c|c|}
\hline County, State & Year Founded/Settlement Name & $\begin{array}{c}\text { Amish } \\
\text { Population } \\
\text { (adherents) }\end{array}$ & $\begin{array}{l}\text { Percent of } \\
\text { County } \\
\text { Population }\end{array}$ \\
\hline $\begin{array}{l}\text { 15. Crittenden, } \\
\text { Kentucky }\end{array}$ & $\begin{array}{l}1977 \text { - Marion } \\
1993 \text { - Salem (partial) }\end{array}$ & $\begin{array}{c}556 \\
56 \\
612\end{array}$ & 6.72 \\
\hline $\begin{array}{l}\text { 16. Schuyler, } \\
\text { Missouri }\end{array}$ & $\begin{array}{l}2003 \text { - Greentop/Queen City (partial) } \\
2008 \text { - Downing (partial) } \\
\end{array}$ & $\begin{array}{c}188 \\
89 \\
277\end{array}$ & 6.68 \\
\hline 17. Parke, Indiana & 1991 - Rockville & 1,077 & 6.37 \\
\hline $\begin{array}{l}\text { 18. Mifflin, } \\
\text { Pennsylvania }\end{array}$ & 1791 - Belleville/Reedsville (partial) & 2,899 & 6.31 \\
\hline $\begin{array}{l}\text { 19. Clark, } \\
\text { Wisconsin }\end{array}$ & $\begin{array}{l}1970 \text { - Spencer (partial) } \\
1975 \text { - Greenwood/Willard } \\
1981 \text { - Granton } \\
1989 \text { - Loyal } \\
1991 \text { - Owen } \\
2005 \text { - Neillsville }\end{array}$ & \begin{tabular}{c|}
68 \\
338 \\
886 \\
505 \\
193 \\
103 \\
2,093 \\
\end{tabular} & 6.26 \\
\hline $\begin{array}{l}\text { 20. Webster, } \\
\text { Missouri }\end{array}$ & 1968 - Seymour/Fordland & 2,252 & 6.16 \\
\hline 21. Buchanan, Iowa & 1914 - Hazelton/Fairbank & 1,135 & 5.43 \\
\hline $\begin{array}{l}\text { 22. Lancaster, } \\
\text { Pennsylvania } \\
\end{array}$ & 1760 - Lancaster/Chester Counties (partial) & 26,270 & 5.17 \\
\hline 23. Coshocton, Ohio & $\begin{array}{l}1808 \text { - Greater Holmes County (partial) } \\
1990 \text { - Walhonding/Warsaw (partial) } \\
1994 \text { - Glenmont/Brinkhaven (partial) } \\
2000 \text { - Howard/"East Knox" (partial) } \\
\text { Total }\end{array}$ & $\begin{array}{c}1,562 \\
37 \\
89 \\
19 \\
1,760 \\
\end{array}$ & 4.92 \\
\hline $\begin{array}{l}\text { 24. Oscoda, } \\
\text { Michigan }\end{array}$ & 1970 - Mio & 424 & 4.87 \\
\hline $\begin{array}{l}\text { 25. Fillmore, } \\
\text { Minnesota }\end{array}$ & $\begin{array}{r}1974 \text { - Canton/Harmony } \\
1993 \text { - Granger (MN)/Cresco (IA) (partial) } \\
\text { Total }\end{array}$ & $\begin{array}{l}859 \\
119 \\
978\end{array}$ & 4.69 \\
\hline
\end{tabular}

*Latest census estimates were used, which in most cases was the estimated county population for 2009.

Altogether, the states of Indiana, Iowa, and Ohio each contain four of the 25 most Amish counties in North America. Missouri includes three counties, followed by two each for Illinois, Kentucky, Pennsylvania and Wisconsin. Michigan and Minnesota have within their state borders one county each in the top 25. 
The Amish Population: County Estimates and Settlement Patterns - Donnermeyer, Anderson and Cooksey

\section{The Future}

The 2010 population count and the 2012 settlement total were used, respectively, to extrapolate, decade by decade, to the year 2050 (see Table 9). For the population estimate, the doubling time of 21.25 years ( $+3.296 \%$ annual increase) was used. We adopted the 1990-2012 average of 15.25 settlements founded annually, and assumed that 20 percent would become extinct (see endnote 5 ). This way of estimating provides a somewhat lower or conservative estimate than only using the annual average number of new settlements founded since 2000, which was higher than the rate during the 1990s, and assuming a 20 percent extinction rate throughout further reduces the projected numbers. However, we prefer to err on the side of conservative.

Table 9 shows settlement estimates rounded to the nearest whole number. We make no assumptions about schisms and divisions which results in some formerly Amish settlements, church districts and families adopting motor vehicles, which could further reduce the figures found in Table 9. Nonetheless, what emerges from these projections is impressive; by 2050, we estimate that the number of Amish adherents will exceed $900,000^{7}$ living and worshipping in 927 settlements. Hence, we could see the Amish population exceeding one million adherents and 1,000 settlements by 2060 at current rates of population increase and settlement growth.

\section{Table 9: The Future - Amish Population and Settlement} Projections to 2050

\begin{tabular}{|c|c|c|}
\hline Year & $\begin{array}{c}\text { Population } \\
\text { (base }-2010)\end{array}$ & $\begin{array}{c}\text { Number of Settlements } \\
\text { (base - 2012) }\end{array}$ \\
\hline $2010 / 2012$ & 250,771 & 463 \\
\hline 2020 & 346,827 & 561 \\
\hline 2030 & 479,675 & 683 \\
\hline 2040 & 663,411 & 805 \\
\hline 2050 & 917,524 & 927 \\
\hline
\end{tabular}

If these estimates are anywhere near hitting the mark, then several consequences related to the economic and social structure of the Amish can be considered. The first is that they will be in a continuous search for opportunities to buy land. We know from their past history of rapid settlement expansion in both Wisconsin (during the 1990s) and Kentucky (during this century) that a decline in the "English" farm population due to Federal government buyout programs (dairy for Wisconsin and tobacco for Kentucky) or 


\section{Journal of Amish and Plain Anabaptist Studies, Volume 1, Issue 1 (April), 2013}

of economic decline in general, will present these opportunities and indicate where the Amish will go next to accommodate their ever-expanding population. We already know (Donnermeyer and Cooksey 2010) that new Amish settlements are being founded in counties which are increasing rural, whether measured by population size or population density. Yet, the Amish also need to be near a town or city with services of various kinds. To quote from a scribe's report from a new settlement in Iowa in the May 2011 issue The Diary (p. 88): "Sigourney is a convenient county seat to do shopping, also hospital, sale barn, etc. And only about 2000 residents.” We expect the Amish to continue to find rural niches for settlements, but generally where community services remain available and accessible. To travel long distances for a doctor, a dentist, a grocery store, etc. requires hiring an "English" driver, which can be expensive. This likely rules out many extremely isolated localities in either the Appalachian region or various western states, but enhances the chances of many new start-ups in regions like western and southern Kentucky, most of Missouri, southern Illinois, southern Iowa, central Minnesota, and as we have witnessed recently, up-state New York. Of note: the western settlements in Colorado and Montana are mostly near small towns where such community services exist, suggesting some expansion west may occur if the right conditions are identified.

Second, we expect that the proportion of Amish men who earn a living from some form of farming will decline, yet, the sheer number of Amish men who farm will increase. In other words, a number of new settlements will be in places where farmland is available and affordable, hence, attractive for the Amish. However, we speculate that the ability to find good farmland will not keep pace with population growth. Hence, a growing proportion of men will be occupied in non-farm jobs. These include, among others: work in sawmills, furniture and cabinet-making, and home construction (i.e., a commodity chain based mostly on wood products); machinery repair and other shop work; and welding, plumbing and other non-wood construction trades. The entrepreneurship of the Amish is already well documented (Kraybill and Nolt 2004), and population pressure may increase the need for greater innovation among the Amish for non-farm business start-ups (Anderson 2012b). In turn, this may be an opening for the adoption of technologies necessary to make a business profitable, which in turn, could modify the ordnungs of many church districts. In a recent conversation with an Amish man living in an Ohio settlement, for example, tension was building between Amish men who were using battery-powered computers to manage their inventory and business records, and their church district's proscription, as expressed through the ordnung, against television monitors.

Another and perhaps more fundamental consequence of population and settlement growth will be associated with the relative autonomy of each church district to establish 
The Amish Population: County Estimates and Settlement Patterns - Donnermeyer, Anderson and Cooksey

its own ordnung, absent of a centralizing church hierarchy for the standardization of beliefs and practices. As already noted, even though there is a remarkable degree of similarity across Amish groups or fellowships, there is also much diversity. We expect this diversity to increase, not only because the number of church districts will increase commensurate with population growth (assuming church district sizes do not change), but because there will be a greater number of new settlements in rural locations which vary in topography, climate, and population density. We expect growing differences in the ordnungs between those found among church districts of newer and far-flung Amish settlements, and the older settlements of the Midwest. In other words, problem-solving to sustain a settlement and to turn it from a mere geographic place of "contiguous proximity” (Hostetler 1993) into a gemeinde or small, rural community (Liepins 2000) will require forms of collective problem-solving that will modify the ordnung of church districts in many of the newer settlements.

Perhaps an increased diversity in the ordnung of church districts of the Amish will lead to future schisms, creating new fellowships of Amish, all of whom still drive buggies. Or, perhaps a more progressive faction will decide it no longer wants to identify with Amish and adopt motor vehicles. Both have happened before (Nolt 2003; Waldrep 2008; Anderson 2011).

Finally, we speculate that the presence of new settlements in rural counties where the Amish have never gone before will have consequences for the "natives," which is a nickname, in addition to the "English," that the Amish apply to the non-Amish, especially when they first move into a new area. Since the sustainability of a new settlement requires families to live close enough to each other to hold a church service and to eventually ordain their own ministers, migration for the Amish is not individualistic, but collective (Anderson 2012a). Will this increase land prices in areas where prices had been stagnant or even in decline? Will an Amish presence turnaround long-term population decline in some rural counties, and improve the local economy both through new business start-ups and a more localized, non-shopping mall approach to spending for groceries and other supplies, plus health and other professional services?

The immediate future predicts a rapid expansion of the Amish population and growth in the number of settlements. Regardless of how accurate are the estimates in Table 9, it seems inevitable that the demographic dynamics of the Amish will be a source of economic, cultural, social, and religious change. 
Journal of Amish and Plain Anabaptist Studies, Volume 1, Issue 1 (April), 2013

\section{Endnotes}

${ }^{1}$ Support provided by the Association of Statisticians of American Religious Bodies, with additional assistance from the Initiative in Population Research, The Ohio State University for GIS mapping, and the Heritage Historical Library in Aylmer, Ontario, Canada with library/archival resources.

${ }^{2}$ For more information about this article, contact Joseph F. Donnermeyer, Room 408C, 2021 Coffey Road, The Ohio State University, Columbus, Ohio 43210

(donnermeyer@osu.edu; 010614451 9830)

${ }^{3}$ The doubling time estimate was developed from statistics on the number of households in various Amish communities as reported in The Diary. Its more formal title is The Diary of the Old Order Churches. It is a monthly publication out of Bart, Pennsylvania (Lancaster County). It publishes news from several hundred communities. In most, but not all, Amish communities, there is a person or a married couple who take on the responsibility of scribe. The scribe submits reports to the editors of The Diary about news from the community for readers living in other communities. Most of the news in The Diary is very mundane and routine - weather, visitors, church activities, births/accidents/deaths. In the January and February issues, however, many scribes report "statistics" for their community from the previous year, including the number of households living there. We gathered all reports from communities whose scribes submitted reports for 2009, 2010, or 2011. We calculated percentage change in the number of households from 132 communities with consecutive reports for 2009 and 2010 (+3.585\%), and 117 communities with consecutive reports from 2010 and 2011 (+2.975). Based on the formula for doubling time $-\approx^{T_{d}=\frac{\log (2)}{\log \left(1+\frac{F}{100}\right)}, \frac{70}{r}}$ - we calculated two doubling times and then a weighted average (weights based on number of settlements included in each calculation). If the current increase in the number of households holds steady, the Amish population is likely to double in 21.25 years. This is a $+3.296 \%$ increase. We view this estimate as conservative because we included only those communities for whom consecutive year reports were available, which necessarily excludes new communities who often experience very rapid growth once they are established.

${ }^{2}$ There are several fellowships of conservative Mennonites who are also "buggy drivers.” They are sometimes mistaken as Amish by the non-Amish, but they do not identify themselves as Amish.

${ }^{3}$ Each year, there are also a few settlements which fail, that is, become extinct. Some new settlements fail to achieve a critical mass of families, and without the ability to 
The Amish Population: County Estimates and Settlement Patterns - Donnermeyer, Anderson and Cooksey

ordain their own ministers, the founding families will disperse to more firmly established settlements. Some older but smaller settlements become extinct because of disagreements over the ordnung, with families relocating to settlements where there is a church district that is more suitable for their interpretation of an Amish way of living. Part of this study was to keep track of these settlements, and delete them from our population count. We estimate that for every 5 settlements founded, there is one which becomes exinct (Donnermeyer \& Cooksey 2010).

${ }^{4}$ Contained within many of the larger settlements, and even some of the smaller settlements, are many other Anabaptist groups, including Amish-Mennonites (who allow motor vehicles) and various other conservative and more progressive Mennonite groups, all which trace their origins back to the Anabaptist movement which began in Switzerland in 1525 (Beachy 2010).

${ }^{6}$ The count of settlements by state is somewhat arbitrary because there are 10 cases where a settlement crosses a state boundary line. We resolved this issue by accepting Luthy's (2009) designation of a settlement in one state or the other, and in turn, he based his decision on the location of the post office (and zip code) used by Amish families to receive mail.

${ }^{7}$ The Young Center “Amish Studies” webpage (see "statistics - population trends") shows a 2012 estimated population of 273,700, up 4.8\% from their 2011 estimate of 261,150 (www2.etown.edu/amishstudies/Index.asp). Using our 2010 estimate as a base, and an annual average increase of 3.296\%, we project a 2012 population of 267,574, which is $2.3 \%$ lower than the Young Center. Also, we calculated a doubling time of 21.25 years, while the Young Center webpage claims a doubling time of 18-20 years. However, a 4.8\% annual increase represents a doubling time of 14.78 years. Obviously, projections using the Young Center statistics will provide a much larger total for succeeding years than our estimates. For example, using the Young Center statistics, as early as 2040, the Amish population will exceed one million. 
Journal of Amish and Plain Anabaptist Studies, Volume 1, Issue 1 (April), 2013

\section{References}

Anderson, Cory. 2011. "Retracing the Blurred Boundaries of the Twentieth-Century 'Amish Mennonite' Identity.” Mennonite Quarterly Review 85:361-412.

Anderson, Cory. 2012a. "Value Systems as a Reason for Migration.” Paper presented at the Annual Meeting of the Rural Sociological Society. Chicago, IL.

Anderson, Cory. 2012b. “The Innovativeness of Laggards.” Paper presented at the Annual Meeting of the Rural Sociological Society. Chicago, IL.

Beachy, Leroy. 2011. Unser Leit: The Story of the Amish. Millserburg, Ohio: Goodly Heritage Books.

Buck, Roy C. 1978. “Tourist Experience in an Old Order Amish Settlement.” Rural Sociology 43:221-224.

Cooksey, Elizabeth and Joseph F. Donnermeyer. 2004. "Go Forth and Multiply: Changes in the Timing of Marriage and Childbearning among Young Amish Women." Paper presented at the Annual Meeting of the Population Association of America. Boston, MA.

Cooksey, Elizabeth and Joseph F. Donnermeyer. 2012. "The Amish in North Amercia: Knowledge, Tradition and Modernity.” Pp. 57-76 in Religion and Knowledge: Sociological Perspectives, edited by Matthew Guest and Elisabeth Arweck. Surrey, England: Ashgate.

Deflem, Matthew. 1999. "Ferdinand Tönnies on Crime and Society: An Unexplored Contribution to Sociological Theory." History of the Human Sciences 12:87-116.

Donnermeyer, Joseph F. and Elizabeth C. Cooksey. 2010. "On the Recent Growth of New Amish Settlements.” Mennonite Quarterly Review 84:181-206.

Grammich, Clifford., Kirk Hadaway, Rich Houseal, Dale E. Jones, Alexei Krindatch, Richie Stanley and Richard H. Taylor. 2012. "2010 U.S. Religion Census: Religious Congregations \& Membership Study.” Kansas City: Association of Statisticians of American Religious Bodies.

Granick, Eve.W. 1989. The Amish Quilt. Intercourse, PA: Good Books.

Greska, Lawrence.P. 2002. Population Growth and Fertility Patterns in an Old Order Amish Settlement. Annals of Human Biology 29:192-201. 
The Amish Population: County Estimates and Settlement Patterns - Donnermeyer, Anderson and Cooksey

Greska, Lawrence P., and Jill E. Korbin 2002. "Key Decisions in the Lives of Old Order Amish: Joining the Church and Migrating to Another Settlement.” Mennonite Quarterly Review 76:373-398.

Hewner, Sharon J. 1998. "Fertility, Migration, and Mortality in an Old Order Amish Community.” American Journal of Human Biology 10:619-628.

Hillery, George.A. Jr. 1955. “Definitions of Community: Areas of Agreement.” Rural Sociology 20:111-123.

Hostetler, John A. 1993. Amish Society. Baltimore: The Johns Hopkins University Press.

Hurst, Charles E., and David L. McConnell 2010. An Amish Paradox: Diversity and Change in the World's Largest Amish Community. Baltimore: The Johns Hopkins University Press.

Iannaccone, Laurence R. 1994. "Why Strict Churches Are Strong.” American Journal of Sociology 99:1180-1211.

Kraybill, Donald B. 1989. The Riddle of Amish Culture. Baltimore: The Johns Hopkins University Press.

Kraybill, Donald B., and Carl D. Bowman. 2001. On the Backroad to Heaven: Old Order Hutterites, Mennonites, Amish, and Brethren. Baltimore: Johns Hopkins University Press.

Kraybill, Donald B., and Steven M. Nolt. 2004 Amish Enterprise: From Plows to Profits. Baltimore: Johns Hopkins University Press.

Kreps, George M., Joseph F. Donnermeyer, and Marty Kreps. 1994. “The Changing Occupational Structure of Amish Males.” Rural Sociology 59:708-719.

Kreps, George M., Joseph F. Donnermeyer, and Marty Kreps. 2004. A Quiet Moment in Time: A Contemporary View of Amish Society. Columbus, OH: Tater Ridge Press.

Liepins, Ruth. 2000. "New Energies for an Old Idea: Reworking Approaches to 'Community' in Contemporary Rural Studies.” Journal of Rural Studies 16:2335.

Luthy, David. 2009. Amish Settlements Across America: 2008. Aylmer, Ontario: Pathway Publishers. 


\section{Journal of Amish and Plain Anabaptist Studies, Volume 1, Issue 1 (April), 2013}

McQuire, M.B. 2002. Religion: The Social Context. Belmont: Wadsworth.

Nolt, Steven. 2003. A History of the Amish. Intercourse, PA: Good Books.

Raber, Aden B. 2013. The New American Almanac. Baltic, OH: Aden B. Raber.

Stevick, Richard A. 2007. Growing Up Amish: The Teenage Years. Baltimore: The Johns Hopkins University Press

Walbert, David. 2002. Garden Spot: Lancaster County, the Old Order Amish, and the Selling of Rural America. Oxford: Oxford University Press.

Waldrep, G.C. 2008. "The New Order Amish and Para-Amish Groups: Spiritual Renewal within Tradition.” Mennonite Quarterly Review 82:395-426.

Warren, Roland. 1978. Community in America. Chicago: Rand McNally.

Wasao, Samson W., and Joseph F. Donnermeyer. 1996. “An Analysis of Factors Related to Parity among the Amish in Northeast Ohio.” Population Studies 50:235-246.

Young Center for Anabaptist and Pietist Studies. 2011. (accessed March 11, 2013).

Amish Population Trends: 2012. www2.etown.edu/amishstudies/PDF/Statistics/ Population_Change_2009_2011.pdf 